\title{
The earliest known list of excommunicates from ducal Normandy
}

Richard Allen*

St John's College, Oxford, OX1 3JP, United Kingdom

(Received 2 June 2012; final version received 22 November 2012)

Of the many additions made by the canons of Rouen cathedral to the Anglo-Saxon manuscript known today as the Benedictional of Archbishop Robert, the shortest is a list of 17 persons who are recorded as having been either 'summoned' (vocandi) or 'excommunicated' (excommunicandi). Although known to scholars for almost two centuries, the list has never been analysed to any great extent, despite the fact that it not only contains the earliest Norman register of excommunicates in existence, but is also apparently unique within the history of the Anglo-Norman realm. This paper examines the list in detail for the first time, and addresses some of the most fundamental questions concerning the rationale behind its creation, its place within the history of excommunication in ducal Normandy, and the identity of the people it names. It will also be argued that the first (and largest) part of the list, the entirety of which is traditionally dated to the reign of Robert Curthose (1087-1106), was most likely compiled during the reign of his father, William the Conqueror (1035-87).

Keywords: excommunication; Benedictional; Archbishop Robert of Rouen;

Normandy; Robert Curthose; William the Conqueror; rebellion 
Among the oldest surviving manuscripts that once belonged to the medieval library of Rouen cathedral is an Anglo-Saxon codex, known traditionally as the Benedictional of Archbishop Robert. ${ }^{1}$ Produced at Winchester towards the end of the tenth century, the manuscript came to the Norman capital at some point during the first half of the eleventh, probably through the agency of Robert, archbishop of Rouen (989-1037). ${ }^{2}$ Long recognised as a chef-d'œuvre of English writing and illumination, the manuscript contains various additions made to the original contents by its Norman owners. ${ }^{3}$ The shortest of these is a list of 17 persons to be either summoned or excommunicated, which is found on the verso of the final folio. ${ }^{4}$ Although known to scholars for almost two centuries, ${ }^{5}$ the list has never been analysed to any great extent, most likely because the names it records appear at first glance to be from among the middling and lower ranks of medieval Norman society. But if these men and women are sometimes of limited social standing, the importance of the source in which they appear more than compensates for such shortcomings. It not only contains the earliest Norman register of excommunicates in existence, but it is also unique, as far as this author is aware, within the history of the Anglo-Norman realm. The aim of this paper, therefore, is to examine the list in detail for the first time and to try to identify the people it names. Traditionally dated to the reign of Robert Curthose (1087-1106), it will be argued below that its genesis most probably lies in the reign of his father, William the Conqueror (1035-87). While it is acknowledged that the study of a potentially 'unique' source has its limitations in terms of our wider understanding of the practice of excommunication in the Middle Ages, it nevertheless offers the opportunity not only to examine an aspect of medieval life that, with regards to Normandy, has yet to receive the attention it deserves, but also to put into better context both the list and the people it names. 
Excommunication was the most serious sanction the medieval church could wield against its members. With a history stretching back to the earliest Christian communities, the ritual involved the exclusion of those found guilty of some crime or misdemeanour from both the religious and secular world until amends had been made for the fault committed. Although the importance with which it was regarded began to wane in the later Middle Ages, ${ }^{6}$ for many it remained an extremely serious business, sometimes prompting a visceral reaction in those at whom it was threatened, ${ }^{7}$ and was described by at least one twelfth-century canonist as tantamount to being exiled from the kingdom of God and given over to the Devil. ${ }^{8}$ It was a sentence that could be pronounced in a highly choreographed ceremony with solemn and fearsome reserve, ${ }^{9}$ but was also a weapon that could be threatened in the heat of the moment, as at least two eleventh-century Norman bishops are known to have done. ${ }^{10}$ Its history has been the subject of much recent scholarship, ${ }^{11}$ although it has hitherto been little studied in relation to ducal Normandy. ${ }^{12}$

\section{[Printer: Plate 1 to be placed near the start of the next paragraph. Caption}

\section{follows.]}

The list of excommunicants (Rouen, BM, MS Y 7 Omont 369, fol. 191v). Image taken from Wilson, ed., Benedictional, plate VI.

Plate 1.

Given the sombre nature of the punishment it records, the list under consideration here, which is printed in an appendix to this article, is unprepossessing. It is only six lines in length, and is consigned to the lower portion of the folio on which it appears. It is not rubricated or otherwise entitled, and is written in as many as 
four different hands, none of which displays any remarkable features. These appear in sequential order, confirming that the list was not the product of a single sitting, but was added to over the course of time. All the hands date, however, from the late eleventh or early twelfth century. The first is responsible for all the names, except the last, in the first four lines. It is distinguished by its capitalised $F$, the crossbar of which extends only to the right; its lower case single-storey $g$, the reverse-c tail of which is not attached to the bowl, and its squat uncial $d$, which is used consistently throughout. Two of these features are found together elsewhere in the Benedictional, but the more angular nature of this text means it is impossible to state with certainty whether the same scribe was responsible. ${ }^{13}$ The second hand, noticeably thicker, in which only the last name of the fourth line is written, is not found elsewhere in the manuscript, with its sloping forked wedges on the top of ascenders, and its lower case single-storey $g$, whose tail comes out of the back of the top compartment with a pronounced curve, serving as useful points of comparison. Similarly, the capital $G$ of the third scribe, which has a crossbar that distinguishes it from the spiralform equivalents of the first hand, with which it shares a number of common features, cannot be seen elsewhere among the later additions to the Benedictional, while only the capital $M$ of the fourth scribe, who wrote the last three words of the list, is distinctive enough to compare with other hands in the manuscript. ${ }^{14}$ If, however, we are unable to identify either the individual scribes or their other works, the various hands can be placed within the family of scripts produced by the scriptorium of Rouen cathedral in the late eleventh and early twelfth centuries. ${ }^{15}$

Establishing the list within the wider history of excommunication also ostensibly poses few problems. From at least the sixth century onwards, canon law stipulated that those who had been excommunicated by one bishop were not to be 
received by others, ${ }^{16}$ a precept whose enforcement can only have been envisaged through the recording and circulating of the names of excommunicants among neighbouring bishops, while the requirement that lists of excommunicates be nailed to church doors, which was first instituted by the Council of Ravenna (877), ${ }^{17}$ was copied into the Decretum of Burchard of Worms. ${ }^{18}$ If we cannot state with certainty that these precepts were known in eleventh-century Normandy, the influx of such material into the Norman capital had been going on for some time, ${ }^{19}$ while nearby abbeys, such as Le Bec, had become important centres for the teaching of canon law, where influential canonical collections, such as the Collectio Lanfranci, were compiled. ${ }^{20}$ Moreover, twelfth-century library catalogues record the presence of Burchard's work both at Le Bec and at the abbey of Fécamp, ${ }^{21}$ while the archbishops of Rouen during this period also took steps to regulate certain aspects of excommunication, as we shall see.

If there is a problem, it is that examples of these mandates being put into practice are hard to find anywhere in Europe, still less within Normandy itself. Bishops might occasionally write to one another concerning the excommunication of a troublesome parishioner, ${ }^{22}$ but examples of the sharing of specially compiled lists seem not to have survived, while there is apparently only one reference from this period to the practice of the nailing a list of excommunicants to a church door, which is recorded in a letter of Gerbert of Aurillac dated to $994 .{ }^{23}$ Moreover, lists or registers of excommunicants are apparently unknown for France and England during this period, ${ }^{24}$ and when names are recorded, they are usually incorporated into excommunication formulae, as is the case for those found in a tenth-century pontifical — a category of service book in which the Rouen manuscript is itself sometimes placed $^{25}$ - from the cathedral of Sens, ${ }^{26}$ or in the lost cartulary of the cathedral of 
Elne. ${ }^{27}$ No known equivalent to the Rouen list survives for Normandy itself, either in terms of a straight list or of names embedded into a formula. Rouen cathedral possessed five benedictionals by the second quarter of the twelfth century, but all except that considered here have been lost. ${ }^{28}$ Circumstances in the other Norman dioceses are little better, with the earliest pontificals and benedictionals dating from the late twelfth century onwards. ${ }^{29}$ It is impossible, therefore, to determine whether the insertion of such a list within a manuscript of this nature represents a practice standard within the eleventh-century Rouen community, or whether it is simply an aberration.

But if it is difficult to place the list in a broader historical context, the incorporation of such a record into a manuscript of this nature is itself somewhat understandable. Liturgical cursing was, after all, the other side of the benedictional coin, while excommunication formulae can be found inserted into other early medieval English manuscripts that by the eleventh century were in Norman hands. ${ }^{30}$ The presence of the list in a manuscript of this nature also corresponds with what we know of many excommunication formulae in France and England during this period, the overwhelming majority of which are not found copied in the category of book one might at first expect. ${ }^{31}$ In Normandy itself, the earliest known formula of excommunication was once found in a Fécamp manuscript, now lost, ${ }^{32}$ which seems to have been written in the first quarter of the eleventh century. ${ }^{33}$ Like other such contemporary texts, however, this formula never actually uses the verb 'to excommunicate' (excommunicare) ${ }^{34}$ but threatens rather 'to curse' (maledicere) or 'to separate' (separare) malefactors from the church. It is instead in the surviving ducal and ecclesiastical charters of Normandy that the first mentions of excommunication can be found, where it is typically used in conjunction with the 
threat of anathema to dissuade those who might violate an agreement or disturb a donation. ${ }^{35}$ The threat itself is most often addressed generally, invariably in a sentence that begins with a phrase such as si quis ('if anyone'). ${ }^{36}$ Some charters, however, record a warning delivered in the first person, normally by a member of the episcopate,${ }^{37}$ although it was not unknown, as in other parts of Europe,${ }^{38}$ for laymen in early eleventh-century Normandy to themselves menace excommunication, ${ }^{39}$ or for them to signal that their donations were protected by excommunication by making the sign of the cross upon the parchment. ${ }^{40}$ Certain acts also record that the threat was delivered verbally to those present, and while this duty was often performed by a bishop, ${ }^{41}$ it might also be carried out by the duke. ${ }^{42}$

Although the idiosyncrasies of Norman charter production may account in part for what appears to be an ad hoc approach to excommunication, ${ }^{43}$ the overall picture in the duchy nevertheless remains far from that in late Anglo-Saxon England, where efforts were made to codify the penalty of excommunication, and where the same excommunication formula was transcribed verbatim into numerous charters. ${ }^{44}$ If, moreover, excommunication was often threatened in Normandy, it has been argued that the threat was not a particularly useful means of deterrence. ${ }^{45}$ Eadmer, for example, records that William the Conqueror would not allow any of his magnates or officials in England to be excommunicated without his consent, irrespective of their crime,${ }^{46}$ and it is likely he pursued a similar policy in Normandy itself. ${ }^{47}$ In the neighbouring county of Anjou, Fulk le Réchin, count of Anjou (1067/8-1109), continued to attend church despite being excommunicated, a fact that did not escape the attention of St Anselm, who wrote to the abbot of Saint-Florent de Saumur in protest. ${ }^{48}$ The complaints of the chroniclers of King Stephen's reign as to the inefficacy of excommunication are well known. ${ }^{49}$ Moreover, since forgiveness is a central tenet of 
the Christian faith, those who had been excommunicated could always earn their absolution through a gift, or some other act of contrition. William fitzOsbern and Roger II de Montgommery, for example, were excommunicated for pillaging the lands of the abbey of Saint-Pierre de Préaux, but made amends by granting a small parcel of land along the banks of the Andelle, ${ }^{50}$ while a certain Robert, son of Bernard, who had been excommunicated for burning four houses and a wine press belonging to the abbot and monks of Saint-Étienne de Caen, was able to receive absolution with the gift of, among other things, 40 solidi from Le Mans. ${ }^{51}$

Excommunication was not only used, however, as a means to protect transfers of property, or to dissuade the theft of a precious item, such as a manuscript. ${ }^{52}$ The proclamation of the Truce of God at the council of Caen in October 1047 was strengthened by the menace of excommunication for those who would violate it. ${ }^{53}$ However, as a letter of Archbishop Maurilius of Rouen (1055-67) suggests, its enforcement in this regard did not always run smoothly. Here the Norman metropolitan can be seen reprimanding one of his suffragans for having excommunicated a monk of Fécamp, who, although guilty of violating the Truce, had not had the Rule of St Benedict properly applied to his case. ${ }^{54}$ This letter is among the first documents in the duchy not only to discuss the proper exercise of excommunication, but also to hint at a move towards greater episcopal control over this particular form of punishment, as was the case in many other parts of France at this time. ${ }^{55}$ A near contemporary text, in which John, bishop of Avranches (1060-7), makes Rannulf, abbot of Mont SaintMichel (1053/5-84/5), his archdeacon, is even more explicit in this regard, since it includes a section instructing the abbot not to speak to those whom he knows to have been excommunicated by the bishop, nor to attempt to excommunicate persons living outside Mont Saint-Michel, without first having consulted him. ${ }^{56}$ It was to be this same 
prelate who, as archbishop of Rouen (1067-79), would for the first time incorporate excommunication as a punishment within the duchy's canonical legislation, ${ }^{57}$ while his successor, William Bona Anima (1079-1110), would further tighten episcopal control over excommunication by threatening to punish priests who excommunicated without the bishop's licence. ${ }^{58}$

Before studying in greater detail the identity of the people named in the list, let us first look more closely at its language and its structure. As has already been noted, the names are divided into two categories, namely the vocandi and the excommunicandi. While the latter is easily understood, the use of the verb vocare, which can be translated and interpreted in various ways, is more problematic. Are we to understand that these individuals were called to face charges relating to excommunication, or had they been summoned for some other purpose in relation to those named among the excommunicated? Should we also consider the list, or at least its first part, to be original, or was the first scribe merely copying into the Benedictional the text of another document that has since been lost, while the other scribes simply added names to a memorandum whose format was convenient to their needs? John Gage, the first person to print the list, which he erroneously dated to the reign of Henry II, did not remark on the distinction between its various parts, simply noting that it contained the names 'of persons to be cited, and of other persons to be excommunicated'. ${ }^{59}$ Likewise, Jacques-Paul Migne, who printed the list among the documents he associated with John of Ivry, bishop of Avranches and archbishop of Rouen, ${ }^{60}$ does not explicitly comment on the matter, but both the title under which the list is printed (Nomina excommunicandorum) and its index entry (Monachi pecuniam habentes excommunicantur) suggest that he considered everybody named therein not only to be monks, but also to have either been excommunicated or summoned to 
answer excommunicable charges. ${ }^{61}$ H.A. Wilson, the modern editor of the Benedictional, is as mute on the point as John Gage, ${ }^{62}$ while Charles Haskins, who associated the list with depredations carried out on ecclesiastical lands during the reign of Robert Curthose, refers elliptically to the notice as 'the list of excommunicates', without indicating whether this description applies to the whole document or not. ${ }^{63}$ The catalogue entry for the Benedictional, compiled by Henri Omont, is equally ambiguous. ${ }^{64}$ The list has largely escaped the attention of more recent scholars, but those who have examined it have not only followed Haskins in his dating, but have assumed that the first part of the document represents a 'list of people to be summoned for excommunication' ${ }^{65}$

In terms both of dating the list and of gaining a better understanding of how we should understand this particular use of vocare, one of the more important identifications that can be made of the persons it names is that of William de Vernon, who appears among the vocandi. ${ }^{66}$ Not to be confused with William I de Vernon (fl. 1107-1166), son of Richard de Redvers (d. 1107), ${ }^{67}$ this William, whose first appearance dates from around 1044, ${ }^{68}$ was the son of Hugh de Vernon, whose own father, Roger, had established himself in the region at an unknown date in the early eleventh century. ${ }^{69}$ Following the exile of Guy de Brionne, who had been invested with the castle of Vernon in $1040 / 1 \times 1047,{ }^{70}$ the duke transferred its control to William, ${ }^{71}$ perhaps on the understanding that he would expand Norman influence into the Vexin, as other lords recently established by the duke were doing elsewhere on the duchy's frontiers. ${ }^{72}$ The narrative sources provide no information about William, but the diplomatic evidence shows that he was an active religious patron, not only founding the collegiate church of Notre-Dame de Vernon, in which he was later buried at some point shortly after $1082,{ }^{73}$ but also acting as benefactor to various 
monastic institutions, including those located within the city of Rouen, in particular the abbey of La Trinité-du-Mont. ${ }^{74}$

With regards to dating the list, the identification of William de Vernon presents us with a clear terminus ad quem for the period either in which the first scribe worked, or for that in which the document from which he was working was drawn up. The fact that the list appears in the Benedictional after an ordo for a council, the insertion of which must have taken place after $1067,{ }^{75}$ allows us to narrow further the period of composition to within a window of around 15 to 20 years. This has important implications for those in the list, such as William d'Arques, ${ }^{76}$ whom we would otherwise be forced to identify with a number of different individuals of the same name. Indeed, these new chronological parameters allow us to say with some certainty that the William d'Arques named among the vocandi alongside William de Vernon is neither William d'Arques, count of Talou, who fled in exile from the duchy after a failed rebellion in $1053,{ }^{77}$ nor is it William d'Arques, monk of Notre-Dame de Molesmes, whose appearances date uniquely from the reign of Robert Curthose, ${ }^{78}$ whom he allegedly served as one of his principal advisers (precipui ducis consiliarii) ${ }^{79}$ The only William d'Arques known to us, in effect, whose appearances coincide chronologically with these dates is William, son of Godfrey, vicomte of Arques. Unable to retain the vicomté held by his father due to the elevation of William, count of Talou, to whom the castle of Arques was granted, he has consequently left only the faintest of traces in the historical record. ${ }^{80}$ Primarily active in England, William, like others named in the list, is recorded in Domesday Book as a tenant-in-chief, his possessions being established in the counties of Suffolk and Kent, where he also held land under Hugh de Montfort, Odo, bishop of Bayeux (1049-97), and Robert Malet, ${ }^{81}$ who was his brother-in-law. ${ }^{82}$ Described as a man 'of great authority' (magne auctoritatis) by the 
record of the plea at Penenden Heath, ${ }^{83}$ both his reputation and the concentration of his activities in the south-east of England seem at first glance to be at odds with the idea that he might have been summoned by the archbishop of Rouen to answer excommunicable charges, rather than that of Canterbury, from whom he held in fief a sulung of land in Fleet (Kent). ${ }^{84}$

The same might also be said, in some respects, of William de Vernon. Of course, the fact that William's principal possession lay in a volatile frontier region, which in the ducal period witnessed everything from lightning cross-border raids to full-scale campaigns, ${ }^{85}$ would have no doubt occasionally required him to act in a manner contrary to the teachings of the Church, and, as we shall see, he is not the only person in the list to be associated with the duchy's border regions. William's collegiate church at Vernon, on the other hand, had been endowed with possessions close to those belonging to Rouen institutions, including the archbishop himself, ${ }^{86}$ and it is not impossible that he was summoned to answer for some perceived infringement on these properties. But unlike some of those named among the excommunicated, who can either be directly linked to excommunicable acts, or were associated with those guilty of behaviour deserving of such punishment, what little we know of William's career presents a very different picture. His burial in the collegiate church of Notre-Dame de Vernon also suggests that, if he had been summoned for excommunication, the issue was eventually resolved, or, more interestingly, that he was summoned in some other capacity. Similar conclusions can be drawn with regards to William d'Arques, since shortly after his death (c.1090), William's daughter (and heir) established, for the soul of her father, the priory of Folkestone. ${ }^{87}$ This foundation was consented to by St Anselm who, as we have seen, was most strict in 
matters of excommunication, and would certainly not have associated with the daughter of an excommunicate. ${ }^{88}$

Such matters are not the only areas in which the two men share commonalities. William d'Arques, like his namesake from Vernon, was also a benefactor of the abbey of La Trinité-du-Mont de Rouen. ${ }^{89}$ Indeed, it was his grandfather, Goscelin, vicomte of Rouen, ${ }^{90}$ who had founded the abbey in $1030,{ }^{91}$ and it was in his capacity as his grandfather's heir that William, having been gathered with other men of 'great authority and exceptional quality' (magne auctoritatis et precipue dignitatis) at the Easter court of 1080, served as a judge in a plea concerning the abbey's possession of the island of Oissel, ${ }^{92}$ which he confirmed by oath as a witness against the wrongful claims of the bishop of Évreux. ${ }^{93}$ Given this judicial role in relation to the abbey's affairs, and the fact that William de Vernon was also a benefactor of La Trinité, the question that arises is whether these men, along with the others named among the vocandi, had perhaps been summoned not to answer for some excommunicable offence, but rather to do suit at the court of the archbishop, where they were to act as judges in cases brought by the abbot of La Trinité against those named among the excommunicated.

Three problems seem, at first glance, to undermine this idea. The first is the fact that the list is written in multiple hands. It seems unlikely that so many scribes would have been responsible for compiling (or copying) such a short memorandum relating to one single event, which means that if the vocandi did serve as judges in relation to the excommunicated then they can only have done so with regards to those names written by the first scribe. The second problem is that neither of the other two vocandi can be linked either to Rouen or to the abbey of La Trinité-du-Mont. The 'son of Hubert' cannot be identified, for obvious reasons, although it is important to 
note that this entry represents a separate individual, rather than another means of identifying William d'Arques, since the $F$ of Filius is capitalised, whereas the $f$ in the entry for Robertus filius Helgonis, the first person to be named among the excommunicated, is not. Roger Arundel, on the other hand, who may have come from the neighbourhood of Caen, ${ }^{94}$ is recorded as a Domesday tenant-in-chief, ${ }^{95}$ but aside from an appearance in a charter in favour of the bishop of Wells, he is otherwise unknown. ${ }^{96}$ According to Domesday, he held Ash Priors (Somerset) wrongfully from the same bishop, ${ }^{97}$ although if any action was taken it seems to have had no effect, since the vill remained in the family until it was given to Taunton Priory by Robert Arundel, who was most likely Roger's son. ${ }^{98}$ Robert served as a local justice under Henry I, ${ }^{99}$ but whether his father ever fulfilled a similar role during the reign of the Conqueror is unknown.

The third problem is that almost none of the excommunicandi recorded by the first scribe can be associated in any way with the Norman capital or its environs. Robert son of Heugon, for example, came from the Pays d'Ouche, near the duchy's south-eastern frontier. He is, nevertheless, one of the few people named in the list who can be directly tied to a misdemeanour worthy of excommunication, since during the abbacy of Osbern, abbot of Saint-Évroult (February 1061-27 May 1066), he seized back the church of Saint-Martin-sur-Guiel, ${ }^{100}$ which he had previously given to the abbey. ${ }^{101}$ Besides his appearance among the excommunicants, however, he cannot otherwise be linked to Rouen or its ecclesiastical institutions. The same is also true of William de Poileio. Examples of this toponym are found throughout medieval France, ${ }^{102}$ while in Normandy it most frequently relates to Poilley in the Avranchin. ${ }^{103}$ In this instance, however, it refers to Poëlé, ${ }^{104}$ a small hamlet about a kilometre to the south-west of Saint-Léger-sur-Sarthe, ${ }^{105}$ and to a member of a family that occupied an 
important position within the entourage of the Montgommery-Bellême clan. ${ }^{106}$ Like others in the list, William was a Domesday tenant-in-chief. ${ }^{107}$ If he is not named among the excommunicandi in relation to the abbey of La Trinite-du-Mont, then the reason(s) behind his excommunication can only be guessed at. His motte and bailey castle, situated in another of the duchy's volatile frontier regions, was located at a strategic crossing point on the river Sarthe, while he also controlled the local church of Saint-Léger de Poëlé (that is, Saint-Léger-sur-Sarthe). ${ }^{108}$ The graveyards of such churches 'in the marches' were prone, according to the decrees of the Council of Lillebonne (1080), to being used as wartime refuges. ${ }^{109}$ The occupying of such a space by force of arms was certainly an excommunicable offence, and it is perhaps no coincidence that among the names of the Rouen list we should find a minor ecclesiastic associated with a place called Saint-Léger.

But if no further link between Walter, deacon of Saint-Léger, and William de Poëlé can be made, the latter's association with the troublesome family of Montgommery-Bellême offers one of the more likely explanations for his excommunication. We have already noted how Roger II de Montgommery was excommunicated for pillaging the lands of the abbey of Préaux, while a Robert de Poëlé (either William's brother or son) was certainly guilty of behaviour deserving of excommunication, since he is accused by Orderic Vitalis of having poisoned a young son of Robert Giroie, who was being held hostage by Robert II de Bellême. ${ }^{110}$ It is also perhaps no accident that William is not the only person in the first part of the list who can be linked to the ambit of the Montgommery-Bellême family. The toponym of Gunfrid de Falaise reveals that he too was associated with an important Montgommery-Bellême stronghold, ${ }^{111}$ and although this individual cannot be positively identified, ${ }^{112}$ we can certainly see others to whom he was most probably 
related in the company of members of both the Montgommery-Bellême and the de Poëlé. ${ }^{113}$

It is with these links in mind, therefore, that we ought perhaps to consider the list in light of one of the most dramatic events of the reign of William the Conqueror, which may have not only resulted in the summoning and excommunication of a large number of individuals from across the Anglo-Norman realm, which is what, after all, the first part of the list presents us with, but of which the seriousness may also have required the apparently unusual step of recording their names. The rebellion of Robert Curthose in 1077/8 posed an unprecedented threat to the duke's authority. As Orderic Vitalis noted, no previous Norman ruler had been troubled in such a way by his progeny, ${ }^{114}$ while Curthose's supporters included men from across the duchy, among whom was Robert II de Bellême. ${ }^{115}$ The first part of the list not only includes men who can be directly or indirectly tied to the ambit of the Montgommery-Bellême family, including those with possessions that lay close to the area around which the rebellion was centred, ${ }^{116}$ but also individuals with links to other Curthose supporters, such as Robert son of Heugon, who held land from William de Breteuil. ${ }^{117}$ Rouen itself also played a significant role in the rebellion, for the revolt began with an unsuccessful bid to seize the city. It is not impossible, therefore, that either the abbey of La Trinité-du-Mont itself, located on a strategic highpoint overlooking the city outside the protection of its walls, ${ }^{118}$ or property belonging to it, was somehow damaged during the attack by followers of the leading rebels, and that what the first part of the list represents is the record of a process concerning those responsible, which was judged by men who were not only of good standing, but also benefactors of the abbey concerned. 
It is unfortunate, of course, that not more of the men named in the first part of the list can be indentified either with Robert II de Bellême or with other Curthose supporters in 1077/8. Herbert du Tot and Geoffrey de Commanville are known only thanks to the list. The toponym of Le Tot is so common as to be found throughout Normandy, ${ }^{119}$ within the city of Rouen itself, ${ }^{120}$ and even in England. ${ }^{121}$ The similiter after Herbert's name is probably meant to indicate some point of resemblance, whether of locality, status or offence, with Walter, deacon of SaintLéger. ${ }^{122}$ Geoffrey's toponym, on the other hand, suggests he hailed from a small hamlet located in the heart of the Giffard fee in the Pays de Caux. ${ }^{123}$ Walter II Giffard, who, by some accounts, was the cousin of William d'Arques, ${ }^{124}$ was later a supporter of Robert Curthose against Henry I, ${ }^{125}$ but he does not seem to have wavered in his loyalty to the Conqueror. He, like many others, was a patron of the abbey of La Trinité-du-Mont. ${ }^{126}$ Richard de la Fontaine (de Fonte) is otherwise unknown, although it should be noted that persons with the toponym de Fontaines (de Fontanis) seem to have been part of the Montgommery-Bellême entourage. ${ }^{127}$ That the narrative sources neither name anyone in the list as a Curthose supporter, nor mention whether those who rebelled were subject to any spiritual punishment, is also somewhat regrettable, as is the fact the list does not mention any of the high-ranking rebels. It is nevertheless possible that the first part of the list simply records the names of some of those captured during the attack on Rouen. Their excommunication would have been both appropriate and politically useful, ${ }^{128}$ since it would have deprived Curthose and his supporters of much needed manpower, and would have ensured that those rebels who remained at large, many of whom had fled into exile, ${ }^{129}$ found themselves in both physical and spiritual isolation from their former conspirators. 
The list, of course, does not include the names of just men. Five women are included among the excommunicandi, of which three appear in the first part of the list. Medieval women, just as their male counterparts, were excommunicated for the destruction of ecclesiastical property, and could prove particularly fearsome opponents, as a letter of Fulbert of Chartres (1006-1028) makes clear. ${ }^{130}$ But the eleventh-century cases of which we are aware tend to involve women of aristocratic rank, ${ }^{131}$ and since the women in our list were not even of significant enough status to be listed under their own name, it might seem unlikely that it was for such a crime they were punished. Such problems seemingly deal another blow to the idea that the first part of the list is to be understood in the context of the Curthose rebellion of 1077/8. It is perhaps no coincidence, however, that just before the first entry concerning a woman we find a mark in the form of an uppercase gamma. Although it is impossible to determine whether this dates from the late eleventh century or not, the use of such a symbol, which is not unlike a reversed pilcrow, is perhaps meant to indicate a distinction between the parts that precede and follow it. It is therefore possible that the first scribe returned to the Benedictional at a later date to add the names of excommunicants to an existing text whose format already suited his needs, much as the other three scribes seem to have done.

Whatever the explanation for the appearance of this mark, the fact that women should appear in the list at all is in itself of some interest. No women are named in the formulae of Sens and of Elne, while the closest known Norman contemporary to the Rouen text, namely a series of fourteenth-century registers of some 1500 excommunicates from the officialité of Cerisy, contain only around 70 women (less than $5 \%$ of the whole). ${ }^{132}$ The vast majority of these are listed anonymously (uxor, relicta $d e$ ), and only eighteen are excommunicated on their own. ${ }^{133}$ Only three are at no point 
associated in the registers with a male relative. ${ }^{134}$ Their crimes include 'stubbornness', ${ }^{135}$ 'manifest offences ${ }^{\text {'136 }}$ and failing to pay a fine levied by a court. ${ }^{137}$ It is entirely possible that the women in our list were punished for similar offences. The penultimate part of the record, however, hints at another explanation. Indeed, the statement added by the third scribe regarding the daughters of Ansguoldus, 'of whom Richard has (habet) one, Gilbert the other', may suggest these men were priests and the women their concubines, since this verb is used elsewhere to describe the relationship between a priest and a female companion. ${ }^{138}$ Adultery, of course, remained a serious concern to medieval church authorities, and it is always possible that the women were simply guilty of what was a fairly common transgression. ${ }^{139}$ Naturally, it would be rash to pretend that such ideas offer anything more than potential clues as to the reason(s) behind the excommunication of these women. After all, we might just as easily identify them as among the group that attacked Archbishop John of Ivry in the abbey of Saint-Ouen de Rouen on 24 August 1073, which, it has been suggested elsewhere, included among its numbers the wives and concubines of the cathedral canons of Rouen, ${ }^{140}$ or argue that the use of the verb habere in this instance indicates nothing more than that these women were in the wardship of the men alongside whom they are named.

As for the women themselves, if they must necessarily remain anonymous, the unusual names of their fathers at least allow us to say something about who they might have been. Benzelin, for example, is such a rare name in the Anglo-Norman world that the woman named here was probably the daughter of one of three individuals. The first is the Benzelin who was an archdeacon in the diocese of Bath and Wells during the reign of Bishop Giso (1061-88). He was a tenant-in-chief in what was then part of Oxfordshire (now within Buckinghamhire), while he also held 
land elsewhere from the bishop of Wells and Ernulf de Hesdin. ${ }^{141}$ Interestingly, one of his possessions lay in the vicinity of those held wrongfully by Roger Arundel. ${ }^{142}$ It is somewhat problematic, of course, that he should not be qualified as archdeacon in the list, although it is certainly not the only source to omit such information, since it is thanks only to Exon Domesday that we are able to identify the Benzelin of Great Domesday as having held this position. ${ }^{143}$ Moreover, no individuals can be positively identified as the children of Benzelin the archdeacon, although a 'Ralph son of Benzelin' is listed among the witnesses of two eleventh-century charters, one of which concerns the abbey La Trinité-du-Mont de Rouen. ${ }^{144}$ Alternatively, Ralph may have been the son of either Benzelin d'Écos, ${ }^{145}$ or of the Benzelin identified as the son of William the Bald (Calvus) de Mesnil-Verclives (de Warcliva), ${ }^{146}$ both of whom appear as witnesses to charters in favour of the very same abbey. ${ }^{147}$ These links to La Trinité-du-Mont are certainly noteworthy, and it is among the charters of this abbey that we also find one of the two individuals named Helton known for the eleventh century. ${ }^{148}$ The other was associated with Odo, bishop of Bayeux, whom he served as steward (dapifer). Like many others in the list, he is recorded in Domesday as holding land in England. His last appearance dates to around $1088 .^{149}$

Any conclusions that can be drawn from this survey are, by the very nature of the list, speculative at best. The limited evidence suggests, for example, that the term vocandi should most likely be understood in the sense of being summoned to perform some sort of duty, rather than to answer accusations relating to a misdemeanour worthy of excommunication, although such ideas cannot be proved absolutely. At least one near-contemporaneous example survives of an episcopal letter summoning a individual of similar status to those in the list to make amends 
for an excommunicable offence, ${ }^{150}$ and while none of the vocandi can apparently be linked in any way to such a crime, their status as landholders would have doubtless sometimes brought them into conflict with ecclesiastical institutions. We have already noted how Roger Arundel held land wrongfully from the bishop of Wells, and how property bequeathed by William de Vernon was located near that belonging to the archbishop of Rouen, a source of possible contention, while William d'Arques was involved in a dispute with the same archbishop concerning the land of Martin-Église, ${ }^{151}$ although the matter was eventually resolved amicably. ${ }^{152}$ Moreover, although it has been argued above that part of the list may be understood in the context of a single event, it is entirely possible that each person named therein was summoned or excommunicated for individual, unrelated reasons. It is still possible, of course, that the influence of Robert de Bellême, whose career is characterised by attacks against ecclesiastical property, ${ }^{153}$ explains why some of the men had been excommunicated, since not only can those in the first part of the list be linked to the de Bellême and their supporters, but the toponym of Ralph d'Argentan, ${ }^{154}$ whose name was added by the second scribe, reveals that he too hailed from a stronghold far from Rouen that was also within the ambit of the Montgommery-Bellême. ${ }^{155}$

There are, moreover, certain issues relating to the list that must, for the moment, remain unresolved. It is unclear, for example, whether the first part represents an original record or simply a copy of a document now lost. Capitulary evidence from the archdiocese of Reims records that the names of sinners were to be recorded on schedulae, in order that the bishop might know whom to punish and when they should be reconciled. ${ }^{156}$ It is possible, therefore, that the first scribe was merely copying the text of such a document, which had become detached 
from that to which it was originally appended. ${ }^{157}$ This may have recorded in more detail the events of a meeting, such as a session of the archiepiscopal court or a local synod, ${ }^{158}$ in which the vocandi acted as judges against those excommunicandi up to and including Geoffrey de Commanville, perhaps for depredations carried out in relation to the abbey of La Trinite-du-Mont during the attack on the city in 1077/8. Aware of the list's existence and of the fact that it related to the abbey of La Trinité, the first scribe returned shortly thereafter to record the names of others excommunicated for offences concerning the same abbey, making sure to distinguish between the two parts by the use of a reverse pilcrow. Later scribes followed suit, with the fourth recording, in the final cryptic words of the list (Monachi pecuniam habentes), the identity of those who had perhaps received what was given by one (or maybe all) of the excommunicants in return for absolution, much like the example of Robert, son of Bernard, and the monks of Caen, noted above. At least one of the excommunicandi must have taken such action, for on 9 December 1091 William de Poëlé not only secured the right to be buried in the cemetery of the abbey of Saint-Martin de Sées, an act which may in itself have had penitential overtones, ${ }^{159}$ but the monks also agreed that he and his sons could become monks there, should they wish it. ${ }^{160}$

But even if the ideas expressed in this essay are often speculative, the need for such conjecture is consistent with the study of texts relating to excommunication in the period before its formalisation in the thirteenth century, when much of the evidence that survives, including the Rouen list, is, as Sarah Hamilton has noted, often ephemeral in nature. ${ }^{161}$ The final question that remains to be considered is why the list should have endured beyond the generations for which it was originally relevant. One might think at first that it records the names of those who had remained 
unrepentant unto death, but this seems unlikely since the activities of some in the list, if their identification above is believed correct, suggest they had received absolution. But if this were true, why, when the practice of erasing the names of excommunicants who had seemingly been reconciled can be traced elsewhere, ${ }^{162}$ was the list not subsequently erased, either in whole or in part? If the first scribe was copying the text of a schedula that formed part of the cathedral archives, then the copy may simply have been viewed in much the same way as those charters copied into a cartulary, which were preserved as an immutable part of an institution's history, despite the fact that many might be rendered obsolete by changes in fortune, while it was not unknown for medieval religious communities to place as much emphasis on preserving the memory of their former tormentors as on that of their benefactors. ${ }^{163}$ It is also possible, of course, that, consigned to the bottom of the final folio of the manuscript, the list was simply forgotten about.

But the fact that the Benedictional was one of the most impressive manuscripts of the cathedral collection would suggest that it cannot have escaped entirely unnoticed by later generations, and, given the role that liturgy played in transmitting memory in the Middle Ages, ${ }^{164}$ it is perhaps no coincidence that the list was not removed from the liturgical manuscript in which it was conserved. That the manuscript does not contain any additions dating beyond the thirteenth century does seem to imply, however, that either it was not regularly used beyond this date, or that its contents had been deemed final, with neither additions nor removals being allowed. Medieval religious institutions were, of course, prodigious list-makers, and dedicated much time and effort to surveying their estates and compiling lists of stocks, treasures and sources of income, while the Normans seem to have been particularly impressed with the ability of the written word to capture and set forever specific moments in time, thus preserving 
for us information that within a generation of its compilation had often become obsolete. ${ }^{165}$ Naming, after all, gives the namer a certain power over that which is named, and excommunication was a tool designed to give the user power to change a person's behaviour by not only excluding him from earthly society, but also threatening the fate of his soul. It was perhaps, therefore, little more than the seriousness of the issue to which the list related, and the ignorance of later generations as to the fate of those named therein, that ensured its preservation, thereby allowing us an enticing insight not only into the uses of this sometimes enigmatic medieval practice, but also into the lives of some of the people against whom, in this instance, it was menaced.

\section{Appendix. The list of excommunicants}

Rouen, BM, MS Y 7 Omont 369, f. 191v.

Printed: Gage, 'Description of a Benedictional', 130. Migne, ed., Patrologia latina, 147: cols 145-6.[CW to sort bib ref.] Wilson, ed., Benedictional, 166.

All contractions have been extended in square brackets. Lines are numbered at the end of each line. The original capitalisation is preserved; the punctuation is editorial.

Hi sunt vocandi, Guill[el]m[us] de Arcis, Filius Hub[er]ti, Roger[us] Arundel, Guill[el]m[us] de Vernu[m]. |1| Hi sunt excommunicandi, Rob[er]t[us] filius Helgonis, Guill[el]m[us] de Poileio, Gunfrid[us] de Falesia, |2| Gualter[us] diaconus de Sancto Leodecario, Herb[er]t[us] de Tot similiter, Goisfrid[us] de Coma[n] vil[la], ${ }^{\text {a }}$ Filia Heltonis, |3| Filia Ansguoldi, ${ }^{\mathrm{b}}$ Ricard[us] de Fonte, Filia Benzelini. Radulfus de Argento[nio]. |4| De filiabus Ansguoldi, ${ }^{c}$ quarum unam habet, Ricard[us], alteram Gisleb[er]t[us]. Monachi pecuniam $|5|$ habentes. 
Notes: a. There is a mark here in the form of an upper-case gamma. b. 'Filia Ansguoldi' is underlined. c. The letter $q$ is written here, followed by an erasure. 


\section{Acknowledgements}

The author is indebted to Bernard Gowers, Mark Hagger, Sarah Hamilton and Stephen Marrit, whose comments on earlier drafts have made this article much better than it otherwise would have been. Any errors that remain are entirely my own.

Richard Allen is a Junior Research Fellow at St John's College, Oxford, and a postdoctoral researcher at the Université de Caen Basse-Normandie, where he is currently working on a project entitled Mémoire et diplomatique : l'édition des actes des évêques de Sées (911-1220). He has published widely on the ecclesiastical history of ducal Normandy (911-1204).

\footnotetext{
*E-mail: richard.allen@sjc.ox.ac.uk

${ }^{1}$ The following abbreviations have been used in this paper: BM: Bibliothèque Municipale; GDB: Great Domesday Book, references taken from J. Morris and others, eds., Domesday Book, 34 vols. (Chichester: Phillimore, 1974-86); LDB: Little Domesday Book, references taken from Morris and
} others, eds., Domesday Book; MGH: Monumenta Germaniae Historica; PL: Patrologia latina cursus completus.

Rouen, BM, MS Y 7 Omont 369. The manuscript has a modern edition: H.A. Wilson, ed., The Benedictional of Archbishop Robert. Henry Bradshaw Society 24 (London: Harrison and Sons, 1903). ${ }^{2}$ Wilson, ed., Benedictional, xi, xiv-xvi. The other archbishop traditionally associated with the manuscript is Robert of Jumièges, archbishop of Canterbury (1051-2). The evidence is slightly stronger for an association with the archbishop of Rouen, though neither prelate can be definitively linked with the manuscript.

${ }^{3}$ Rouen, BM, MS Y 7 Omont 369, ff. 1v-3, 40v-41, 81v-82v, 171v-180, 181-3, 188-90, 191v. The dates assigned to the handwriting of these pages by Henry Wilson should largely be ignored. See instead, R. Gameson, 'La Normandie et l'Angleterre au XIe siècle: le témoignage des manuscrits', in 
La Normandie et l'Angleterre au moyen âge (Actes du colloque de Cerisy-la-Salle, 4-7 octobre 2001), eds. P. Bouet and V. Gazeau (Caen: Publications du CRAHM, 2003), 158.

${ }^{4}$ Rouen, BM, MS Y 7 Omont 369, f. 191v.

${ }^{5}$ The earliest known printed reference is J. Gage, 'A Description of a Benedictional, or Pontifical, Called "Benedictionarius Roberti archiepiscopi", an Illuminated Manuscript of the Tenth Century, in the Public Library at Rouen', Archaeologia 24 (1832): 130.

${ }^{6}$ R. Hill, 'The Theory and Practice of Excommunication in Medieval England', History 42 (1957): 111.

${ }^{7}$ Such was the reaction of William IX, duke of Aquitaine, who, in 1114, threatened to behead the bishop of Poitiers if he finished pronouncing the excommunication against him: R.A.B. Mynors, R.M. Thomson and M. Winterbottom, eds. and trans., William of Malmesbury, Gesta regum Anglorum: the History of the English Kings, 2 vols. (Oxford: Clarendon Press, 1998-9), 1: 784. This was presumably an extreme reaction, and, if the sentence of excommunication was seen as unwarranted, most probably took the same approach as Ida, countess of Hainaut, who wrote to Lambert, bishop of Arras (10931115), in an effort to convince him not to excommunicate her: J.-P. Migne, ed., Patrologia latina cursus completus, 221 vols. (Paris: Migne, 1844-64), 162: col. 667.[CW to sort ref]

${ }^{8}$ Gratian, Decretum, Causa XI, Quaestio III, c. XI and c. XXI, in Corpus iuris canonici, ed. E. Friedberg. 2 vols. (Leipzig: Tauchnitz, 1879-81), 1: cols. 646, 648-9.

${ }^{9}$ For a description of the ceremony, which was rarely performed, see H.C. Lea, Studies in Church History: the Rise of the Temporal Power, Benefit of Clergy, Excommunication (Philadelphia: H.C. Lea and Co., 1869), 338; F.D. Logan, Excommunication and the Secular Arm in Medieval England: a Study in Legal Procedure From the Thirteenth to the Sixteenth Century. Pontifical Institute of Mediaeval Studies, Studies and texts 15 (Toronto: Pontifical Institute of Mediaeval Studies, 1968), 13; idem, 'Excommunication', in Dictionary of the Middle Ages, eds. J.R. Strayer and others. 13 vols. (New York: Scribner, 1983-9), 4: 536-8.

${ }^{10}$ These were John of Ivry, archbishop of Rouen (1067-79), and Robert, bishop of Sées (c.1071$c .1081$ ), both of whom threatened excommunication against monastic communities who they felt had wronged them: R. Allen, 'The Acta archiepiscoporum Rotomagensium: Study and Edition', Tabularia 'Documents' 9 (2009), 42; D. Bates, ed., Regesta regum Anglo-Normannorum: the Acta of William I, 1066-1087 (Oxford: Clarendon Press, 1998), no. 29 (Version I). 
${ }^{11}$ Besides those works already referenced above, for a good general introduction, see E. Vodola, Excommunication in the Middle Ages (Berkeley: University of California Press, 1986); L. Little, Benedictine Maledictions: Liturgical Cursing in Romanesque France (Ithaca: Cornell University Press, 1993); V. Beaulande, Le malheur d'être exclu? Excommunication, réconciliation et société à la fin du moyen âge. Publications de la Sorbonne, Histoire ancienne et médiévale 84 (Paris: Publications de la Sorbonne, 2006). A very useful survey of the historiography of excommunication as it was at the end of the twentieth century can be found in G. Steele Edwards, 'Ritual Excommunication in Medieval France and England, 900-1200' (Ph.D. thesis, Stanford University, 1997), 4-10.

${ }^{12}$ An exception is L. Hicks, 'Exclusion as Exile: Spiritual Punishment and Physical Illness in Normandy, c.1050-1300', in Exile in the Middle Ages: Selected Proceedings from the International Medieval Congress, University of Leeds, 8-11 July 2002, eds. L. Napran and E.M.C. van Houts. International medieval research 13 (Turnhout: Brepols, 2004), 146-55.

${ }^{13}$ Rouen, BM, MS Y 7 Omont 369, ff. 179v-180.

${ }^{14}$ See, for example, Rouen, BM, MS Y 7 Omont 369, f. 2 v.

${ }^{15}$ Both the spiralform capital $G$ of the first scribe and the capital $M$ of the fourth, which is made of two bows, with a rounded, lozenge-shaped, closed bow on the left, are two features common in documents produced at the eleventh-century cathedral. For other examples, see Rouen, BM, MS Y 27 Omont 1405, ff. 26-36; Rouen, Archives départementales de la Seine-Maritime, G 1846, G 4014, G 8739, G 8740 and $14 \mathrm{H} 189$ (lower half).

${ }^{16}$ For example, see Council of Lyons (567 or 570), canon 4, in F. Maassen, ed., Concilia aevi Merovingici. MGH, Concilia 1 (Hanover: MGH, 1893), 140; Council of Pavia (850), canon 11, and Council of Valence (8 January 855), canon 13, in W. Hartmann, ed., Die Konzilien der Karolingischen Teilreiche 843-859. MGH, Concilia 3 (Hanover: MGH, 1984), 225, 360; Council of Troyes (878), canon 5, in G. Mansi, ed., Sacrorum conciliorum nova et amplissima collectio, 31 vols. (Venice, 175793), 17(a): col. 350; Council of Melfi (1089), canon 15, in R. Somerville, with S. Kuttner, eds., Pope Urban II, the Collectio Britannica, and the Council of Melfi (1089) (Oxford: Clarendon Press, 1996), 257.

17 'Curae sit omnibus episcopis excommunicatorum nomina omnino tam vicinis episcopis, quam suis parochianis pariter indicare, eaque in celebri loco posita prae foribus ecclesiae cunctis convenientibus inculcare': Council of Ravenna (877), canon 10, in Mansi, ed., Sacrorum conciliorum, 17(a): col. 339. 
${ }^{18}$ Burchard of Worms, Decretorum libri XX, lib. XI, cap. 49, in Migne, ed., Patrologia latina, 140: col. 868.[CW to sort bib ref.]

${ }^{19}$ For discussion, see R. Allen, ‘Avant Lanfranc. Un réexamen de la carrière de Mauger, archevêque de Rouen (1037-1054/55)', in Autour de Lanfranc (1010-2010): réforme et réformateurs dans l'Europe du Nord-Ouest (XIe-XIle siècles) (Actes du colloque de Cerisy-la-Salle, 29 septembre-2 octobre 2010), eds. V. Gazeau, J. Barrow and F. Delivré (forthcoming).

${ }^{20}$ For the Collectio, see Z.N. Brooke, The English Church and the Papacy: from the Conquest to the Reign of John (Cambridge: Cambridge University Press, 1931), 57-83; N. Álvarez de las Asturias, La 'Collectio Lanfranci’. Origine e influenza di una collezione della chiesa-anglo-normanna, trans. M. Scipioni (Milan: Giuffrè, 2008). For a bibliography of works, see L. Kéry, Canonical Collections of the Early Middle Ages (ca. 400-1140): a Bibliographical Guide to the Manuscripts and Literature (Washington, DC: Catholic University of America Press, 1999), 239-43. For the contents of the Collectio, see M. Philpott, 'Lanfranc's Canonical Collection and the "Law of the Church"', in Lanfranco di Pavia e l'Europa del secolo XI nel IX centenario della morte (1089-1989), ed. G. d'Onofrio. Italia sacra (Herder editrice e libreria) 51 (Rome: Herder, 1993), 131-47.

${ }^{21}$ Of course, it is impossible to know at what point Burchard's work entered each institution, but the fact that it is not found in an eleventh-century catalogue of the Fécamp library suggests that in this instance it was not until the twelfth century. For the catalogues, see H. Omont, ed., Catalogue général des manuscrits des bibliothèques de France. Départements. Tome premier. Rouen (Paris: Plon, Nourrit, 1886), xxiv-xxvi; H. Omont, ed., Catalogue général des manuscrits des bibliothèques de France. Départements. Tome second. Rouen (suite et fin) (Paris: Plon, Nourrit, 1888), 385-94. On the history of the libraries of Le Bec and Fécamp, see G. Nortier, Les bibliothèques médiévales des abbayes bénédictines de Normandie. Fécamp, Le Bec, Le Mont Saint-Michel, Saint-Évroul, Lyre, Jumièges, Saint-Wandrille, Saint-Ouen (Caen: Caron et Cie, 1966), 6-60; S. Lecouteux, 'Sur la dispersion de la bibliothèque bénédictine de Fécamp. Partie 1: identification des principales vagues de démembrement des fonds', Tabularia 'Études' 7 (2007): 1-50. For the spread of canon law collections in Normandy in the period $c .1140-c .1230$, the roots of which lay in the preceding century, see J. Peltzer, Canon Law, Careers and Conquest: Episcopal Elections in Normandy and Greater Anjou, c.1140-c.1230.

Cambridge studies in medieval life and thought, 4th series, 71 (Cambridge: Cambridge University Press 2008), 56-67. 
${ }^{22}$ See, for example, F. Behrends, ed. and trans., The Letters and Poems of Fulbert of Chartres (Oxford: Clarendon Press, 1976), no. 79; Ivo de Chartres, Epistolae, in Migne, ed., Patrologia latina, 162: nos. Ixxv and lxxvi, cols. 97-8;[CW to sort bib ref.] H. Müller, ed., Päpstliche Delegationsgerichtsbarkeit in der Normandie: 12. und frühes 13. Jahrhundert. Studien und Dokumente zur Gallia Pontificia 4. 2 vols. (Bonn: Bouvier, 1997), 2: no. 53; Lambert of Arras, Epistolae, in Migne, ed., Patrologia latina, 162: no. xxx, col. 659.[CW to sort bib ref]

${ }^{23}$ F. Weigle, ed., Die Briefsammlung Gerberts von Reims. MGH, Die Briefe der deutschen Kaiserzeit 2 (Berlin: MGH, 1966), no. 202.

${ }^{24}$ It is possible, of course, to find lists of excommunicates either produced by a figure associated with the Anglo-Norman realm, or preserved in documents that would have circulated in Normandy, but these tend to concern the excommunication of national or international figures. See, for example, the list of those excommunicated by Thomas Becket: A. Duggan, ed. and trans., The Correspondence of Thomas Becket, Archbishop of Canterbury, 1162-1170, 2 vols. (Oxford: Clarendon Press, 2000), 1: no. 262; or that appended to the proceedings of the Council of Reims (1119): W. Holtzmann, 'Zur Geschichte des Investiturstreits (Englische Analekten II.)', Neues Archiv der Gesellschaft für Ältere Deutsche Geschichtskunde 50 (1935): 318-19. Elsewhere, a manuscript from Cambrai contains a list of malefactores, drawn up in the late tenth-century, which was perhaps meant to be read out during a ceremony of excommunication: Cambrai, Médiathèque municipale, MS 327 (309), f. 193. I am extremely grateful to M. Charles Mériaux for bringing this list to my attention and for the suggestion as to its use.

${ }^{25}$ Henry Wilson noted that the manuscript is not strictly a benedictional in the narrower sense, but might be 'described with equal or greater accuracy as a pontifical': Wilson, ed., Benedictional, $\mathrm{x}-\mathrm{xi}$. ${ }^{26}$ St Petersburg, Public Library, MS lat. Q v.I., no. 35, ff. 105v-107. The text is printed in A. Staerk, ed., Les manuscrits latins du Ve au XIIIe siècle conservés à la Bibliothèque impériale de Saint-

Pétersbourg, 2 vols. (St Petersburg, 1910), 1: 172-3. For discussion, see Little, Benedictine

Maledictions, 34-5; S. Hamilton, 'Remedies for "Great Transgressions": Penance and

Excommunication in Late Anglo-Saxon England', in Pastoral Care in Late Anglo-Saxon England, ed.

F. Tinti. Anglo-Saxon studies 6 (Woodbridge: Boydell Press, 2005), 94, 103.

${ }^{27}$ For an edition and translation, with commentary, see Edwards, 'Ritual Excommunication', Appendix A.3, 141-5. 
${ }^{28} \mathrm{~A}$ catalogue of the cathedral's library as it was in the time of Archbishop Geoffrey Brito (1111-28) contains the following entry: 'Benedictionarius Roberti archiepiscopi et IIII ${ }^{\text {or }}$ alii': Omont, ed., Catalogue. Tome premier, $\mathrm{x}$.

${ }^{29}$ For a list of the earliest surviving collections of Norman benedictionals, see J. Laporte, 'Bénédictions épiscopales à Paris (Xe s.)', Ephemerides liturgicae 71 (1954): 156. For a summary of the debate surrounding the manuscript assigned to the cathedral of Avranches, see M. Mansfield, The Humiliation of Sinners: Public Penance in Thirteenth-Century France (Ithaca: Cornell University Press, 1995), 202, nn. 24-5.

${ }^{30}$ Paris, Bibliothèque Nationale, MS lat. 943, f. 1v. This is the Sherborne Pontifical; for a description of its contents, see N.K. Rasmussen, Les pontificaux du haut moyen âge: gènese du livre de l'évêque. Spicilegium sacrum Lovaniense, Études et documents 49 (Leuven: Spicilegium sacrum Lovaniense, 1998), 259-62. For the formula, which was perhaps added at the abbey of Jumièges, see Hamilton, 'Remedies for "Great Transgressions", 96.

${ }^{31}$ Edwards, 'Ritual Excommunication', 18-19.

${ }^{32}$ It is printed in E. Martène, ed., De antiquis ecclesiae ritibus, 4 vols. (Bassan: n.p., 1788), 2: 325.

${ }^{33}$ For discussion of the date, see Little, Benedictine Maledictions, 8, n. 13.

${ }^{34}$ See for example, Edwards, 'Ritual Excommunication', Appendix A.2, 139, and Appendix C.4, 212 14.

${ }^{35}$ The earliest known threat of excommunication to be issued by a Norman prelate dates from $979 \times$ 989, and is found in a charter of Hugh, archbishop of Rouen (942-89): R. Poupardin, ed., Recueil des chartes de l'abbaye de Saint-Germain-des-Prés, 2 vols. (Paris: H. Champion, 1909-32), 1: no. xliv. For the ducal charters, see M. Fauroux, ed., Recueil des actes des ducs de Normandie de 911 à 1066. Société des Antiquaires de Normandie 36 (Caen: Caron et Cie, 1961), nos. 16, 17, 33, 43, 49, 69-71, $93,95,98,107,110,120,122,133,144,160,161,204,204 b i s, 211,214$ and 226. For the distinction between excommunication and anathema, see Little, Benedictine Maledictions, 30-44.

36 'Et si quis, stimulatus iaculo diabolicę calliditatis, huic dono calumpniam inferre praesumpserit totius aecclesię excommunicationibus perhenniter detineatur...': Fauroux, ed., Recueil, no. 16 (c.1015).

${ }^{37}$ Fauroux, ed., Recueil, no. 69 (13 April × 30 April 1033).

${ }^{38}$ B.-M. Tock, 'Les mutations du vocabulaire latin des chartes du XIe siècle', Bibliothèque de l'École des Chartes 155 (1997): 134. 
${ }^{39}$ Fauroux, ed., Recueil, no. $211(1055 \times 1066)$.

40 'Hanc cartam ego Hugo firmo sub firma excommunicatione per hoc sig+num crucis': Fauroux, ed., Recueil, no. 107. This is Hugh de la Ferté, who issued the charter in question in $1046 \times 1047$ or possibly 1048. See also Fauroux, ed., Recueil, no. 43.

${ }^{41}$ See, for example, the threat delivered during the dedication of the church of Marigny (Manche, cheflieu de canton), which was performed by Geoffrey de Montbray, bishop of Coutances (1048/9-93): C. Fierville, ‘Étude sur le marquisat de Marigny’, Mémoires de la Société Académique du Cotentin 1 (1875): 87-8, n. 1. The practice of explaining the excommunication orally is first recorded by Regino of Prüm (c.845-915): Little, Benedictine Maledictions, 38.

42 'Fecit etiam Willelmus comes a predictis episcopis ante altare Sanctę Marie excommunicationem fieri super omnes illos qui molirentur hoc donum violare...': Fauroux, ed., Recueil, no. 133 (25 December 1053/4).

${ }^{43}$ Norman charters during this period were normally produced by the beneficiary, which resulted in a far greater variation between documents, as opposed to those prepared in England, which were usually drawn up at the royal court. For discussion of Norman practices with regards to ducal and royal charters, see Bates, ed., Regesta, 9-35.

${ }^{44}$ For discussion, see Hamilton, 'Remedies for "Great Transgressions"', 97-102.

${ }^{45}$ E. Tabuteau, Transfers of Property in Eleventh-Century Norman Law (Chapel Hill: University of North Carolina Press, 1988), 207.

${ }^{46}$ Eadmer, Historia novorum in Anglia, ed. M. Rule. Rolls Series 81 (London: Longman, 1884), 10.

${ }^{47}$ This was certainly the case by the end of the twelfth century: 'Le très ancien coutumier de Normandie', in E.-J. Tardif, ed., Coutumiers de Normandie, 2 vols. (Rouen, 1881-1903), 1: 1-2 (cap. II).

${ }^{48}$ F.S. Schmitt, ed., S. Anselmi Cantuariensis archiepiscopi opera omnia, 6 vols. (Edinburgh: Nelson, 1940-51), 3: no. 65, lines 15-31. There has been some confusion as to whom this letter was written. It was sent in summer 1078, and was simply addressed 'to the reverend Abbot William' ('abbati reverendo Willelmo'). Schmitt notes that one of the manuscripts from which he worked includes the note 'abbas Fiscannensis', that is Fécamp in Normandy, but claimed this was chronologically impossible, since he believed William de Rots only became abbot in 1079. William, however, began his abbacy in early 1078 , and this has led certain scholars to identify him as the recipient: e.g. W. 
Fröhlich, trans., The Letters of Saint Anselm of Canterbury. Cistercian studies series 96, 97, 142.3 vols. (Kalamazoo: Cistercian Publications, 1990-4), 1: no. 65; V. Gazeau, Normannia monastica, 2 vols. (Caen: Publications du CRAHM, 2007), 2: 111. Schmitt also notes, however, that another of the manuscripts contains the marginal note 'abbas Samurensis', that is Saumur in Anjou. This house was governed by a William between 1070 and 1118, and since the excommunicated count is only referred to as 'your count' ('comes quidem voster'), it seems Anselm is most likely referring to Fulk le Réchin. For the reasons behind his excommunication, see O. Guillot, Le comte d'Anjou et son entourage au XIe siècle, 2 vols. (Paris: A. et J. Picard, 1972), 1: 116.

${ }^{49}$ D. Whitelock, D.C. Douglas and S.I. Tucker, eds., The Anglo-Saxon Chronicle: a Revised Translation (London: Eyre and Spottiswoode, 1961), 199; E. King, ed., K.R. Potter, trans., William of Malmesbury, Historia novella: the Contemporary History (Oxford: Clarendon Press, 1998), 72; K.R. Potter and R.H.C. Davis, eds. and trans., Gesta Stephani (Oxford: Clarendon Press, 1976), 156. Some of these complaints are, however, unfair: G.J. White, Restoration and Reform, 1153-1165: Recovery From Civil War in England. Cambridge studies in medieval life and thought, 4th series, 46 (Cambridge: Cambridge University Press, 2000), 65-6.

${ }^{50}$ D. Rouet, ed., Le cartulaire de l'abbaye bénédictine de Saint-Pierre-de-Préaux (1034-1227). Collection de documents inédits sur l'histoire de France, série in-8 $8^{\circ}, 34$ (Paris: CTHS, 2005), no. A164 $(1050 \times 20$ February 1071). For discussion of this case, and others like it, see Tabuteau, Transfers of Property, 20.

${ }^{51}$ Caen, Archives départementales du Calvados, $1 \mathrm{~J}$ 41, ff. 53v-54 (1101 × 1107).

${ }^{52}$ Such is the case for the Livre noir of the abbey of Saint-Ouen de Rouen, in which Abbot Nicholas (1042-92) inserted a threat of excommunication against potential thieves (Rouen, BM, MS Y 41 Omont 1406, f. 23). The text is printed in Gazeau, Normannia monastica, 2: 248 n. 65. For various other examples, see J.W. Clark, The Care of Books: an Essay on the Development of Libraries and their Fittings, From the Earliest Times to the Eighteenth Century (Cambridge: Cambridge University Press, 1901), 77-8.

${ }^{53}$ The exact nature of the Truce proclaimed at Caen can only be considered by reference to texts compiled at a later date: G. Bessin, ed., Concilia Rotomagensis provinciae (Rouen: n.p., 1717), 39. For discussion, see M. de Boüard, 'Sur les origines de la Trêve de Dieu en Normandie', Annales de Normandie 9 (1959): 169-89. The threat of excommunication was nevertheless reiterated when the 
Truce was re-imposed at the end of the eleventh century: M. Chibnall, ed. and trans., The Ecclesiastical History of Orderic Vitalis, 6 vols. (Oxford: Clarendon Press, 1969-80), 5: 26.

${ }^{54}$ L. Delisle, 'Choix de pièces inédites. XI. Cérémonial d'une épreuve judiciaire', Bibliothèque de l'École de Chartes 18 (1857): 255.

${ }^{55}$ Tock, 'Les mutations du vocabulaire', 135.

${ }^{56}$ K.S.B. Keats-Rohan, ed., The Cartulary of the Abbey of Mont-Saint-Michel (Donington: Shaun Tyas, 2006), Appendix II, no. 5; P. Bouet and O. Desbordes, Chroniques latines du Mont Saint-Michel (IXeXIIe siècle). Manuscrits du Mont Saint-Michel, Textes fondateurs 1 (Caen: Presses universitaires de Caen, 2009), 375-8 (1061). For discussion of this agreement, see R. Allen, “'A Proud and Headstrong Man”: John of Ivry, Bishop of Avranches and Archbishop of Rouen, 1060-79', Historical Research 83 (2010): 197-8.

${ }^{57}$ Council of Rouen (1072), canons 10 and 16, in Chibnall, ed., Orderic, 2: 288-90.

${ }^{58}$ Council of Lillebonne (1080), canon 26, in Chibnall, ed., Orderic, 3: 32.

${ }^{59}$ Gage, 'Description of a Benedictional', 130.

${ }^{60}$ Migne, ed., Patrologia latina, 147: cols. 9-280.[CW to sort bib ref]

${ }^{61}$ Migne, ed., Patrologia latina, 147: cols 145, 1318.[CW to sort bib ref]

${ }^{62}$ Wilson, ed., Benedictional, 198.

${ }^{63}$ C. Haskins, Norman Institutions (Cambridge, MA: Harvard University Press, 1918), 63 n. 4.

${ }^{64}$ Omont, ed., Catalogue. Tome premier, 70.

${ }^{65}$ Hamilton, 'Remedies for "Great Transgressions", 102-3.

${ }^{66}$ Vernon, Eure, chef-lieu de canton. For the various Latin renderings of this place name, see F. de Beaurepaire, ed., Les noms des communes et anciennes paroisses de l'Eure (Paris: A. et J. Picard, 1981), 206.

${ }^{67}$ For the complex history of his family, and for an excellent genealogy, see D. Power, The Norman Frontier in the Twelfth and Early Thirteenth Centuries. Cambridge studies in medieval life and thought, 4th series, 62 (Cambridge: Cambridge University Press, 2004), 206-7, 526-7.

${ }^{68}$ B. Guérard, ed., Cartulaire de l'abbaye de Saint-Père de Chartres, 2 vols. (Paris: Imprimerie de Crapelet, 1840), 1: 178-9 (cap. no. lii).

${ }^{69} \mathrm{P}$. Bauduin, La première Normandie (Xe-XIe siècles): sur les frontières de la haute Normandie: identité et construction d'une principauté (Caen: Presses universitaires de Caen, 2004), 232-7. 
${ }^{70}$ R.H.C. Davis and M. Chibnall, eds. and trans., The Gesta Guillelmi of William of Poitiers (Oxford: Clarendon Press, 1998), 8.

${ }^{71}$ Bauduin, La première Normandie, 235-6.

${ }^{72}$ D. Bates, Normandy Before 1066 (London: Longman, 1982), 177.

73 'Sciant presentes ac futuri, quod ego Richardus de Vernone pro salute animae meae, antecessorum et successorum meorum, concedo, de proprio sigillo confirmo donationem, quam primis Guillelmus de Vernone, antecessor meus, cuius corpus in ecclesia de Vernone iacet, donavit ecclesiae Vernonensi, quando Gislebertus Ebroicensis episcopus eam dedicavit': Évreux, Archives départementales de l'Eure, G 288. The bishop is Gilbert son of Osbern, bishop of Évreux (1071-1112). Daniel Power places William's death 'in about 1086', without explanation: Power, Norman Frontier, 330. He was certainly dead by 1089 , since the town of Vernon had been passed to Richard de Redvers by this date: R. Bearman, ed., Charters of the Redvers Family and the Earldom of Devon, 1090-1217. Devon and Cornwall Record Society, new series 37 (Exeter: Devon and Cornwall Record Society, 1994), 2. ${ }^{74}$ A. Deville, ed., 'Cartulaire de l'abbaye de la Sainte-Trinité du Mont de Rouen', in Cartulaire de l'abbaye de Saint-Bertin, ed. B. Guérard. Collection de documents inédits sur l'histoire de France. Première série, Histoire politique; Collection des cartulaires de France 3 (Paris, 1841), 457, no. 1xx; Fauroux, ed., Recueil, no. 130; Bates, ed., Regesta, no. 234. William also witnessed or gave his consent to donations made by others to the abbey: Deville, ed., 'Cartulaire de Sainte-Trinité', 432, no. xxii; 457, no. lxx; 460, no. lxxviii. He was also a patron of the abbey of Le Bec: A. du Monstier, Neustria pia (Rouen: n.p., 1663), 492; Bates, ed., Regesta, no. 166.

${ }^{75}$ This ordo refers to Maurilius, archbishop of Rouen, as dead, i.e. 'of venerable memory' (venerabilis memoriae): Wilson, ed., Benedictional, 155. Wilson claims incorrectly that the text of the ordo 'appears to have been written in the latter part of the 12th century': Wilson, ed., Benedictional, 153, $\mathrm{n}$. 2. Its modern editor, however, has recognised it as 'ein Nachtrag der 2. Hälfte des 11. Jh.’: H. Schneider, ed., Die Konzilsordines des Früh- und Hochmittelalters. MGH, Ordines de celebrando concilio (Hanover: MGH, 1996), 568.

${ }^{76}$ Arques-la-Bataille, Seine-Maritime, cant. Offranville.

${ }^{77}$ For William, who was the son of Richard II, duke of Normandy (996-1026), see D.C. Douglas, William the Conqueror: the Norman Impact Upon England (London: Eyre and Spottiswoode, 1964), 
40-1; Bauduin, La première Normandie, 309-10. William appears in a charter dated to 1059, but both the witness list and dating clause contain inconsistencies: Fauroux, ed., Recueil, no. 142. ${ }^{78}$ Chibnall, ed., Orderic, 4: 224; Haskins, Norman Institutions, Appendix E, no. 4a; G. Chevrier and M. Chaume, eds., Chartes et documents de Saint-Bénigne de Dijon: prieurés et dépendances des origines à 1300, 2 vols. (Dijon: Société des Annales de Bourgogne, 1943-86), 1: nos. 385, 386, 391. ${ }^{79}$ Chibnall, ed., Orderic, 4: 186.

${ }^{80}$ For William, see T. Stapleton, 'Some Observations Upon the Succession to the Barony of William of Arques', Archaeologia 31 (1846): 216-37; D.C. Douglas, ed., The Domesday Monachorum of Christ Church Canterbury (London: Offices of The Royal Historical Society, 1944), 42-4. ${ }^{81} \mathrm{GDB}$, f. 9v; LDB, ff. 320, 407, 431v. William can probably also be identified with the William son of Godefridus, who held three messuages in Dover (f. 1): Stapleton, 'Some Observations', 217.

${ }^{82}$ For William's wife Beatrix, see V. Brown, ed., Eye Priory Cartulary and Charters. Suffolk charters, 12, 13. 2 vols. (Woodbridge: Boydell Press for the Royal Historical Society, 1992-4), 2: 6.

${ }^{83}$ Bates, ed., Regesta, no. 69. He can also be seen acting as a judge in the shire court of Kent, where he is described as among the 'magnates' (optimates) of the county: Bates, ed., Regesta, no. 88.

${ }^{84} \mathrm{GDB}$, f. $3 \mathrm{v}$.

${ }^{85}$ J. Green, 'Lords of the Norman Vexin', in War and Government in the Middle Ages. Essays in Honour of J. O. Prestwich, eds. J. Gillingham and J.C. Holt (Woodbridge: Boydell Press, 1984), 4763.

${ }^{86}$ The canons at Vernon were granted land at Giverny (Eure, cant. Les Andleys), whose church belonged to the abbey of Saint-Ouen de Rouen (Fauroux, ed., Recueil, no. 53) as well as the fourth part of all the forest of Vernon, which was 'between the forest of the archbishop of Rouen and the forest of St Ouen' ( ‘... quae est inter forestam arch[i]episcopi Rothomagensis et forestam sancti Audoeni’): Évreux, Archives départementales de l'Eure, G 288. The forest of St Ouen is now Bois-Jérôme-Saint-Ouen (Eure, cant. Écos).

${ }^{87}$ W. Dugdale, Monasticon Anglicanum, ed. J. Caley and others, 6 vols. in 8 (new edition, London: n.p., 1846), 4: 674. William died without male issue. For the marriages of his two daughters, whose children inherited the toponyms of their fathers (e.g. Dugdale, Monasticon, 4: 26, 674), see Brown, ed., Eye Cartulary, 2: 6-7. William's family must have left some residual presence in Suffolk, however, for the surname 'de Arches' can be found there during the reign of Henry III: P. Dryburgh and B. Hartland, 
eds., Calendar of the Fine Rolls of the Reign of Henry III, Preserved in The National Archives, 3 vols. (Woodbridge: Boydell Press, 2007-9), 1: 139.

${ }^{88}$ In a letter to Ernulf, prior of Canterbury, Anselm explains that he cannot communicate with those excommunicated for lay investiture 'without danger to my soul' ('communicare non possum sine animae meae periculo'): Schmitt, ed., Anselmi opera, 5: no. 311 line 9; Fröhlich, trans., Saint Anselm, 3: no. 311. The idea that excommunication was contagious goes back to the third century: Vodola, Excommunication, 16-17.

${ }^{89}$ Deville, ed., 'Cartulaire de Sainte-Trinité', 434, no. xxv.

${ }^{90}$ For his grandfather's career, see J.-M. Bouvris, 'Contribution à une étude de l'institution vicomtale en Normandie au XIe siècle, l'exemple de la partie orientale du duché: les vicomtes de Rouen et de Fécamp', in Autour du pouvoir ducal normand Xe-XIIe siècles, Cahier des Annales de Normandie 17 (Caen: Annales de Normandie, 1985), 149-74.

${ }^{91}$ Fauroux, ed., Recueil, no. 61.

${ }^{92}$ Seine-Maritime, cant. Saint-Étienne-du-Rouvray.

${ }^{93}$ Bates, ed., Regesta, no. 235.

${ }^{94}$ J. Green, The Aristocracy of Norman England (Cambridge: Cambridge University Press, 1997), 64. ${ }^{95}$ GDB, ff. 82v, 94v.

${ }^{96}$ Bates, ed., Regesta, no. 286. He witnesses as Rotgerus Derundel. For the identification of this as Roger Arundel, see S. Keynes, 'Giso, bishop of Wells', Anglo-Norman Studies 19 (1997): 243. The suggestion that Roger was from La Bréhoulière (Manche, cant. Subligny) in K.S.B. Keats-Rohan, Domesday People: a Prosopography of Persons Occurring in English Documents, 1066-1166, I, Domesday Book (Woodbridge: Boydell Press, 1999), 395, does not stand up to closer inspection, for not only is La Bréhoulière associated with the Earls of Arundel, to whom Roger had no connection (C. Thorn and F. Thorn, eds., Domesday Book. 7, Dorset [Chichester: Phillimore, 1983], chapter 47, notes), but the link between La Bréhoulière and the Earls has long been called into question: J.H. Round, 'Review: Étienne Dupont, Recherches historiques et topographiques sur les compagnons de Guillaume le Conquérant', English Historical Review 23 (1908): 122.

${ }^{97}$ GBD, f. 89 v.

${ }^{98}$ London, The National Archives, C53/121, m. 6 (Charter Roll, 8 Edward III), charter of Henry II in an inspeximus dated 1 October 1334. The charter is printed in Dugdale, Monasticon, 6.1: 166-7, where 
Ash (Aissam) is incorrectly rendered Dissam. I owe the manuscript reference to the edition currently being prepared by Professor Nicholas Vincent of Henry II's charters, an advance copy of which I have been fortunate enough to consult.

${ }^{99} \mathrm{~J}$. Green, The Government of England Under Henry I. Cambridge studies in medieval life and thought, 4th series, 3 (Cambridge: Cambridge University Press, 1986), 128, n. 62.

${ }^{100}$ Saint-Martin-sur-Guiel, now Heugon, Orne, cant. La Ferté-Frênel.

${ }^{101}$ Chibnall, ed., Orderic, 2: 96. If Robert was excommunicated for this act, however, the punishment seems to have persuaded him to return the church, since it is listed among the abbey's possessions in a confirmation charter of Henry I: A. Le Prévost, Orderici Vitalis Angligenae, coenobii Uticensis monachi, Historiae Ecclesiasticae libri tredecim, 5 vols. (Paris: Renouard, 1838-55), 5: 198.

${ }^{102}$ E. Nègre, ed., Toponymie générale de la France: étymologie de 35,000 noms de lieux, 3 vols. (Geneva: Droz, 1990-1), 1: 507, 520-1, 580.

${ }^{103}$ F. de Beaurepaire, ed., Les noms des communes et anciennes paroisses de la Manche (Paris: Picard, 1986), 177. Poilley, Manche, cant. Ducey. Families associated with Poilley provided members of the cathedral chapters at Avranches and Coutances: D. Spear, The Personnel of the Norman Cathedrals During the Ducal Period, 911-1204 (London: University of London, School of Advanced Study, Institute of Historical Research, 2006), 21, 99-100, 121.

104 The name of this hamlet is also rendered as Poëley, Poêle, Poeley or Poelley. The form used here is that preferred by the Institut géographique national de France.

${ }^{105}$ Saint-Léger-sur-Sarthe, Orne, cant. Alençon.

${ }^{106}$ William's brother Robert served as dapifer to Roger II de Montgommery in the Saosnois and at the castle of Lurson: G. Louise, La seigneurie de Bellême, Xe-XIIe siècles, 2 vols. (Flers: Pays BasNormand, 1992-3), 2: 280-1.

${ }^{107}$ GDB, ff. 111r-v. His toponym is rendered as de Poilgi or de Poillgi, while it appears as de Poilleio, de Poillei and de Poileio in Exon Domesday: H. Ellis, ed., Libri censualis vocati Domesday-book additamenta ex codic. antiquiss., Exon' Domesday, Inquisitio Eliensis, Liber Winton', Boldon book (London: Record Commission, 1816), 387-90. Caroline and Frank Thorn identified William as from the Avranchin (C. Thorn and F. Thorn, eds., Domesday Book. 9, Devon, 2 vols. [Chichester: Phillimore, 1985], 2: chapter 21), but this seems unlikely, since the cartulary of Saint-Martin de Sées records that he donated some of his English lands to the abbey: Sées, Bibliothèque de l'Évêché, MS 
non coté, ff. 120-1. This would have been an unusual house for William to have patronised were he from a region over $120 \mathrm{~km}$ to the west, whereas Saint-Martin was the monastic establishment closest to the hamlet of Poëlé in the eleventh century. Of course, it was not unknown for individuals to donate to religious houses far from their centre of power. The twelfth-century lords of Vernon (Eure), for example, were patrons of the abbey of Montebourg (Manche), and at least two of them, including William I de Vernon, were buried there, but this is because their line descended from a family originally from the Cotentin: Bearman, ed., Charters of the Redvers, 1-5; Power, Norman Frontier, $330-1$.

${ }^{108}$ Sées, Bibliothèque de l'Évêché, MS non coté, ff. 65v and 67r-v (cartulary of Saint-Martin de Sées).

${ }^{109}$ Council of Lillebonne (1080), canon 12, in Chibnall, ed., Orderic, 3: 28.

${ }^{110}$ Chibnall, ed., Orderic, 4: 294. Chibnall did not identify the toponym (Poileio), which she rendered in English as Poillée, while Auguste Le Prévost identified it as Poillé-sur-Vègre (Sarthe, cant. Brûlon) (Le Prévost, ed., Orderici Vitalis, 3: 419, n. 2). Robert, however, was undoubtedly a member of the Poëlé clan.

${ }^{111}$ Roger II de Montgommery and Robert II de Bellême held the vicomté of Falaise (Calvados, chef-lieu de canton): Louise, La seigneurie de Bellême, 2: 20, 202.

${ }^{112}$ It was a Gunfrid de Falaise who founded the hospital of Saint-Jean de Falaise in 1127, but it is unlikely that he and the Gunfrid of our list are the same man. The original of the foundation charter still survives as Caen, Archives départementales du Calvados, H 4033.

${ }^{113}$ A Gilbert de Falaise, son of Serlo, is listed, along with Robert de Poëlé, as one of the barons (barones) present at the court of Roger II de Montgommery in 1078 × 1089: Sées, Bibliothèque de l'Évêché, MS non coté, ff. 71v-72 (cartulary of Saint-Martin de Sées).

${ }^{114}$ Chibnall, ed., Orderic, 3: 112.

${ }^{115}$ Stephanie Mooers (Christelow), “"Backers and Stabbers”: Problems of Loyalty in Robert Curthose's Entourage', Journal of British Studies 21 (1981): 16.

${ }^{116}$ William de Poëlé's castle at Saint-Léger-sur-Sarthe, for example, lay less than a day’s ride (approximately $33 \mathrm{~km}$ ) from the rebel stronghold of Rémalard (Orne, chef-lieu de canton).

${ }^{117}$ Chibnall, ed., Orderic, 2: 32, 36; D. Crouch, The Beaumont Twins: the Roots and Branches of Power in the Twelfth Century. Cambridge studies in medieval life and thought, 4th series, 1 (Cambridge: Cambridge University Press, 1986), 104-5. 
${ }^{118}$ The abbey was located on a promontory to the east of the city in what is now the modern commune of Bonsecours. Its exposed location meant that it was subject to frequent attacks throughout its history: Deville, ed., 'Cartulaire de Sainte-Trinité', 407. According to Orderic, so worried was Henry I by the rumour that the abbey had been fortified in 1118 by Hugh de Gournay and Stephen d'Aumale, partisans of William Clito, that he immediately marched his army from L'Aigle to confront the rebels: Chibnall, ed., Orderic, 6: 198.

${ }^{119}$ C. de Beaurepaire, ed., Dictionnaire topographique du département de Seine-Maritime: comprenant les noms de lieux anciens et modernes, 2 vols. (Paris: Bibliothèque nationale, 1982-4), 2: 980-1.

120 'L'hôtel du Tot était situé rue Malpalu; c'était un fief avec tour et colombier. En face se trouvait la rue de la Grosse Tour du Tot, aujourd'hui rue de la Grosse-Bouteille [today, rue des Augustins]': P.-A. Chéruel, Histoire de Rouen pendant l'époque communale 1150-1382, 2 vols. (Rouen, 1843-4), 2: 284. ${ }^{121}$ The fee of Tot (in Paston, Cambridgeshire) was associated with the abbey of Peterborough: E. King, Peterborough Abbey, 1086-1310: a Study in the Land Market (Cambridge: Cambridge University Press, 1973), 24, 29, 32, 38, 44-5.

${ }^{122}$ Wilson, ed., Benedictional, 198.

${ }^{123}$ Today, Ferme de la Haute Commanville, Seine-Maritime, cant. Cany-Barville, com. Le Haut de Barville. For the holdings of this fee, a large number of which were located in the modern canton of Cany-Barville, see J. Le Maho, 'L'apparition des seigneuries châtelaines dans le Grand-Caux à l'époque ducale', Archéologie Médiévale 6 (1976): 38-46.

124 The relationship was questioned by Douglas, ed., Domesday Monachorum, 43, but is generally accepted by modern scholars: K.S.B. Keats-Rohan, 'Domesday Book and the Malets: Patrimony and the Private Histories of Public Lives', Nottingham Medieval Studies 41 (1997): 49; Green, Aristocracy, 56.

${ }^{125}$ C. Warren-Hollister, Henry I (New Haven: Yale University Press, 2001), 132-3.

${ }^{126}$ Deville, ed., 'Cartulaire de Sainte-Trinité', 444-5, no. xlv.

${ }^{127}$ A donation of a certain Mazelin, son of Fulk de Fontaines (Fontanis), was confirmed by Roger II de Montgommery and other members of his family, suggesting that the donor enjoyed a position of some prominence within the count's entourage: Sées, Bibliothèque de l'Évêché, MS non coté, ff. 38v-39 
${ }^{128}$ The punishment of excommunication for rebellion had been incorporated into English conciliar legislation some five years earlier at the Council of Winchester (1072), canon 9: D. Whitelock, M. Brett and C.N.L. Brooke, eds., Councils \& Synods, With Other Documents Relating to the English Church. I, A.D. 871-1204, 2 vols. (Oxford: Clarendon Press, 1981), 2: 606.

${ }^{129}$ Chibnall, ed., Orderic, 2: 358.

${ }^{130}$ The bishop wrote to Franco, bishop of Paris (1020-30), explaining that he had not excommunicated a certain woman of Laon, who was guilty of destroying church property, because 'there was no one who would dare to notify her that we had excommunicated her': Behrends, ed., The letters of Fulbert of Chartres, no. 79.

${ }^{131}$ A. Livingstone, 'Aristocratic Women in the Chartrain', in Aristocratic Women in Medieval France, ed. T. Evergates (Philadelphia: University of Pennsylvania Press, 1999), 69.

${ }^{132}$ This is a document known as the Registre de l'Officialité de Cerisy. It was once conserved at the departmental archives of La Manche (cote H 1407), but was destroyed on 6 June 1944. Fortunately, an edition was printed in the late nineteenth century: G. Dupont, 'Le registre de l'officialité de Cerisy (1347-1457)', Mémoires de la Société des Antiquaires de Normandie 30 (1880): 271-662. The registers of excommunicates, the earliest of which dates from 1323, are found at pages 361-2, 401-7, $408-14,422-7,430-2,451-5,458-62,465-70,476-9,481-5,490-2,501-5,508,522-3,528-9,539-$ $40,542-3,552-5,564-5,595-7$ and $600-1$.

${ }^{133}$ Dupont, 'Registre de Cerisy', 361-2, 410-12, 425, 451, 455, 466, 483, 501, 529, 542, 601.

${ }^{134}$ Dupont, 'Registre de Cerisy', 362 (Nicholaa la Couetee), 410 (Nicolaa Piederche) and 451 (Iohanna la Merelee).

135 'Claricia relicta Hebeti Fain pro contumacia contra Petrum le Foulon, presbiterum’: Dupont, 'Registre de Cerisy', 361 (Regestrum excommunicatorum anno 1323).

136 'Uxor Iohannis l'Aloier pro manifesta offensa contra ministrum officii; item contra Iohannem Genas, clericum, pro contumacia': Dupont, 'Registre de Cerisy', 425 (Regestrum excommunicatorum anno 1339).

137 'Philippota uxor Gauffridi de Canteleyo pro deffectu solutionis emendarum curie', Dupont, 'Registre de Cerisy', 542 (Regestrum excommunicatorum anno 1397).

${ }^{138}$ T. Bonnin, ed., Regestrum visitationum archiepiscopi Rothomagensis. Journal des visites pastorales d'Eude Rigaud, archevêque de Rouen (Rouen: Auguste Le Brument, 1852), 20, 26. For the punishment 
of the concubines of priests, including their excommunication, in later medieval Europe, see J.

Brundage, Law, Sex, and Christian Society in Medieval Europe (Chicago: University of Chicago Press, 1987), 474-6.

${ }^{139}$ Brundage, Law, Sex, and Christian Society, 207-9.

${ }^{140}$ A. Alexander, 'Riots, Reform and Rivalry: Religious Life in Rouen, c.1073-c.1092', Anglo-Norman Studies 33 (2010): 30.

${ }^{141}$ GDB, ff. 70, 89v, 160.

${ }^{142}$ According to Exon Domesday, he held 11/2 hides in the hundred of Kingsbury West (Somerset), which included Ash Priors, held by Roger: Ellis, ed., Libri censualis, 71.

${ }^{143}$ D.E. Greenway, ed., Fasti Ecclesiae Anglicanae, 1066-1300. VII, Bath and Wells (London: Institute of Historical Research, 2001), 25.

${ }^{144}$ Fauroux, ed., Recueil, no. 135; Bates, ed., Regesta, no. 201.

${ }^{145}$ Écos, Eure, chef-lieu de cant.

${ }^{146}$ Mesnil-Verclives, Eure, cant. Fleury-sur-Andelle.

${ }^{147}$ Fauroux, ed., Recueil, no. 202; Deville, ed., 'Cartulaire de Sainte-Trinité', 465, no. lxxxvii. Another charter of La Trinité, which is either dated $1078 \times 1120$ or $1139 \times$ after 1163 , is witnessed by a certain Benzelin de Civières (Eure, cant. Écos): Deville, ed., 'Cartulaire de Sainte-Trinité', 456, no. lxviii. Since Civières is less than $2 \mathrm{~km}$ from Écos, it is possible that this Benzelin is either the same person as, or a relative of, Benzelin d'Écos, who seems to have died before or during the early years of the reign of Robert Curthose: Tabuteau, Transfers of Property, 125.

${ }^{148}$ Fauroux, ed., Recueil, nos. 83, 104.

${ }^{149}$ For his career and Domesday holdings, see Keats-Rohan, Domesday People, I, 247.

${ }^{150}$ The letter is from Manassas II, archbishop of Reims (1096-1106), to Alelmus de Passo and the clerks of the same place: Migne, ed., Patrologia latina, 162: cols 654-5.[CW to sort bib ref]

${ }^{151}$ Seine-Maritime, cant. Dieppe-Est.

${ }^{152}$ Bates, ed., Regesta, no. 230.

${ }^{153}$ For Robert's career, see K. Thompson, 'Family and Influence to the South of Normandy in the Eleventh Century: the Lordship of Bellême', Journal of Medieval History 11 (1985): 215-26; idem, 'Robert of Bellême Reconsidered', Anglo-Norman Studies 13 (1990): 263-86; Louise, La seigneurie de Bellême, 2: 168-74. 
${ }^{154}$ Orne, chef-lieu de canton. Ralph cannot otherwise be identified. He was perhaps related to Warner d'Argentan, who, on 4 February 1083, granted certain possessions to the monks of Saint-Martin de Sées within and around the castle of Argentan: Sées, Bibliothèque de l'Évêché, MS non coté, f. 94 (cartulary of Saint-Martin de Sées). Warner had two sons named Renaud and Osmund. His father was named Herbran. A certain William d'Argentan was a monk of Saint-Martin: Sées, Bibliothèque de l’Évêché, MS non coté, f. 116v (cartulary of Saint-Martin de Sées).

${ }^{155}$ The castle of Argentan was granted to Arnulf, the son of Roger II de Montgommery: Louise, $L a$ seigneurie de Bellême, 2: 20, 191-2.

${ }^{156}$ S. Hamilton, The Practice of Penance, 900-1050 (Woodbridge: Royal Historical Society, 2001), $70-1$.

${ }^{157}$ For a near-contemporaneous example of a charter, with its own witness list, to which has been attached a small strip of parchment recording the names of those who witnessed its contents at a later date, see Rouen, Archives départementales de la Seine-Maritime, 9 H 1764. The text is printed in Haskins, Norman Institutions, Appendix E, 291-2.

${ }^{158}$ For the suggestion by a bishop that someone be excommunicated in a synod so that the punishment might be brought to the attention of the wider ecclesiastical community, see Behrends, ed., The Letters of Fulbert of Chartres, no. 79. The second half of the eleventh century saw a flourishing of such meetings in Normandy. For discussion, see R. Foreville, 'The Synod of the Province of Rouen in the Eleventh and Twelfth Centuries', in Church and Government in the Middle Ages: Essays Presented to C.R. Cheney on his 70th Birhtday, eds. C.N.L. Brooke and others (Cambridge: Cambridge University Press, 1976), 19-39.

${ }^{159}$ For the suggestion that burial in such a location may have had a penitential purpose, see D. Park, 'Medieval Burials and Monuments', in The Temple Church in London: History, Architecture, Art, eds. R. Griffith-Jones and D. Park (Woodbridge: Boydell Press, 2010), 71-3.

${ }^{160}$ Sées, Bibliothèque de l'Évêché, MS non coté, ff. 65v and 67 (cartulary of Saint-Martin de Sées). The family would henceforth take an active interest in the abbey's affairs: Sées, Bibliothèque de l'Évêché, MS non coté, ff. 38, witnessed by Hugh, son of Renaud de Poëlé, $1100 \times 1114$; ff. 67r-v, charter of Robert son of William de Poëlé, 1101; f. 70v, witnessed by William de Poëlé, 23 March 1108; f. 72, witnessed by Robert de Poëlé, $c .1080 \times 1094$; f. 89, witnessed by William, clerk, son of William de Poëlé, 8 April 1109; f. 93, witnessed by William, son of William de Poëlé, 1102; f. 102v, 
witnessed by William de Poëlé, 1111; ff. 120r-v, charter of William de Poëlé, 1093; ff. 120v-121, witnessed by William de Poëlé and his son Robert, 1095.

${ }^{161}$ Hamilton, 'Remedies for "Great Transgressions"', 101-2.

${ }^{162}$ The evidence comes from an early eleventh-century sacramentary-cum-benedictional from the cathedral of Noyon, which contains an excommunication formula in which the names of the excommunicants have been erased, apparently as a result of their reconciliation: London, British Library, Add. MS 82956, f. 1v. The fact that the amendments were made above the line suggests the text was designed for repeated use. I am grateful to Dr Sarah Hamilton for bringing this text to my attention and for the suggestion as to its use.

${ }^{163}$ For discussion with regards to the list of Cambrai noted above, see L. Jégou, "« Qui perd gagne ». La place de l'honneur dans la mémoire judiciaire aux IXe-Xe siècles', in Une histoire de la mémoire judiciaire de l'Antiquité à nos jours, eds. O. Poncet and I. Storez-Brancourt. Études et rencontres de l'École des chartes 29 (Paris: École nationale des chartes, 2010), 302 ; idem, L'évêque, juge de paix. L'autorité épiscopale et le règlement des conflits (VIIIe-XIe siècle) (Turnhout: Brepols, 2011), 32-3. ${ }^{164}$ On the liturgy as the enactment of memory in the Middle Ages, see in particular K. Schmid and J. Wollasch, eds., Memoria: der geschichtliche Zeugniswert des liturgischen Gedenkens im Mittelalter. Münstersche Mittelalter-Schriften 48 (Munich: W. Fink, 1984).

${ }^{165}$ M.T. Clanchy, From Memory to Written Record: England, 1066-1307. 2nd edn. (Oxford: Basil Blackwell, 1993), 32-5. 